\title{
sciendo
}

\section{The impact of lending on bancassurance activity}

\author{
Elda MARZAI (ABLIZ) \\ The Bucharest University of Economic Studies, Bucharest, Romania \\ elda.abliz@yahoo.com
}

PICBE | 171

\begin{abstract}
Due to financial crisis, and especially because of prudence in lending (retail, micro, and corporate), banks are looking for new sources of income, and bancasurance is clearly a potential source of revenue. Thus, in the financial market, the interests of two major components of it are met: banks maximize commission income, and insurers make access to the large customer base of banks. Bancassurance is a distribution channel of insurance products through bank branches, bringing important advantages for banks, insurance companies and customers. The main advantage for the bank is that earns fee amount from the insurance company, the insurance company increases customers data base and market share, the client satisfy his financial needs and requests in the same institution. Considering that in Romania, banks and insurers do not provide information on the number of insurances sold via the bancassurance distribution channel, as well as commissions obtained by banks for the insurance sale, to determine the development of bancassurance in Romania, we used the statistical data provided by the National Bank of Romania, on credit growth and data provided by The Financial Supervision Association, on the evolution of gross written premiums. Bancassurance is one of the most important insurance distribution channels, accounting for approximately $36 \%$ of the global insurance market, in 2016, Europe's insurers generated total premium income of $€ 1189 \mathrm{bn}$ and had $€ 10112 b n$ invested in the economy. Regarding to the risks of bancassurance business for banks and insurers, they mainly concern distinct capital requirements for the banking and insurance systems, which will be covered by the Basel III and Solvency II directives. This paper aims to analyze the influence of credit on the bancassurance activity in the last 5 years in Romania, the economic, political and legal factors that have a negative impact on the development of bancassurance, and also the calculating the correlation coefficient r (Pearson's coefficient) and his result.
\end{abstract}

Keywords: bancassurance, loans, insurance, gross written premiums, credit risk, Pearson coefficient

\section{Introduction}

Financial markets are constantly changing, in order to maximize profits, but also to meet the needs and requirements of our clients. So, there are trying to improve their products and create new ones, like bancassurance.

The term of bancassurance is defined in the relevant legislation as the intermediation activity of insurance products, which are sold together with the products of credit institutions and non-banking financial institutions, through bank branches. Bancassurance is an operation of selling life and non-life insurance products, using a bank's customers. In some developed countries, the life insurance product sales attaining around 80 percent market shares (e.g.Spain), but opposite, in others developed countries the market shares are much lower, or in some countries, bancassurance wasn't officially recognized as a distribution channel and it wasn't implemented.

DOI: $10.2478 /$ picbe-2019-0016, pp. 171-181, ISSN 2558-9652| Proceedings of the $13^{\text {th }}$ International Conference on Business

Excellence 2019 
In Romania, bancassurance activity is mainly related to retail banking. In addition to life insurance, the banks in Romania also offer health, fire, and other damage to property: damage to property (buildings and content, machinery) for land transport: Casco, civil liability insurance, property insurance Transit: Cargo, Financial Loss: Business Interruption or Air and Shipping: P \& I and H \& M. In 2013, banks have increasingly turned their attention to corporate customers, so they have also begun to sell through this distribution channel also complex insurance products (eg: photovoltaic park assurances, wind turbines).The prudential measures for the implementation of bancassurance activity are regulated by both BASEL III and Solvency II, the activity being divided between the two sectors: banking and insurance.

The Basel III framework is a regulatory directive created as a response to the global financial crisis from 2007-2009. The objectives of this regulatory framework are to improve the financial sector's ability to absorb financial and economic shocks, improve risk management and governance, as well as the transparency of credit institutions. The Basel III reforms focused on ensure that banks have sufficient capital to keep the credit flow in the economy; on improving to reduce credit risk, this may lead to an increase in the cost of credit; and introducing an international framework for mitigating excessive liquidity risk and maturity transformation, through the Liquidity Coverage Ratio and Net is a Stable Funding Ratio. Solvency II is an European supervision regime for insurance and reinsurance undertakings, which establish a set of capital requirements and risk management standards. The Solvency II Directive consists of three pillars, similar to the Basel II Banking Directive: capital requirements, risk measurement and management, and reporting. The first pillar deals with the quantitative requirements of the Directive involved in the calculation of Solvency Capital Requirement (SCR) and Technical Reserve (TP). The SCR size indicates which capital should be kept available for the company to operate, when the available capital is below the SCR limit, it can lead to a high risk for policyholders and will be an early warning indicator for the authorities. Pillar II focuses on the qualitative requirements of the Directive, which include an adequate governance system with a proper risk management approach. Pillar III refers to the public disclosure of information on the company's operations and results, ensuring an adequate degree of transparency. Periodic reports include reconciled data with financial reporting to increase report reliability.

The macroeconomic environment for European insurers improved in 2016. The European economy continued to grow, albeit at a slower pace, with the real gross domestic product (GDP) of the $28 \mathrm{EU}$ member states increasing by 1.9\%, after 2.3\% growth in 2015 . This - now confirmed - EU economic recovery occurred amid decreasing or stagnating GDP growth rates in the world's other large economies. 


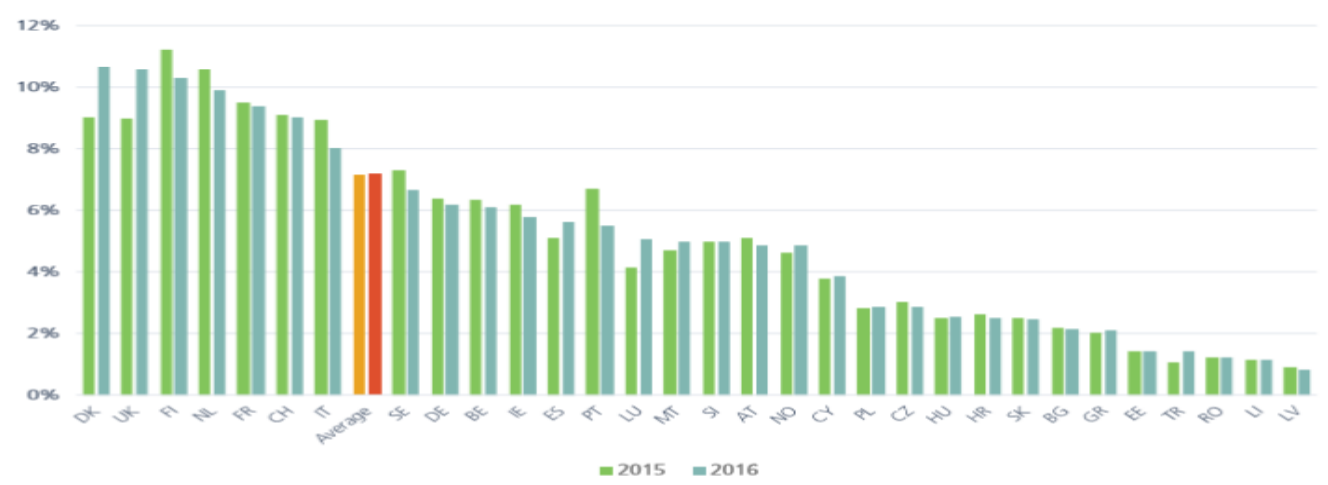

Chart 1. Total premiums as \% of GDP (by country) in 2015-2016

PICBE | 173

Source: European Insurance in Figures, retrieved from: https://www.insuranceeurope.eu/sites/default/files/attachments/WEB_European\%20Insurance\%

\section{Literature review}

20in\%20Figures\%20-\%202016\%20data.pdf

In the literature, various studies have been carried out on the impact of the interaction between banks and insurance companies, if their cooperation does or does not add value, the profitability and efficiency of bancassurance implementation was analyzed, but we didn't find relevant studies about the influence of lending on the activity bancassurance, as well as the factors that influence the success of bancassurance implementation.

Many researchers were preoccupied about the partnership between banks and insurance companies, financial conglomerates, or if bancassurance as value for banks.

In their work, Iman van Lelyveld and Klaas Knot, "Does conglomerates destroy value or not? Evidence for the EU ", focus in particular on the assessment of bank-insurance conglomerates. To determine whether the conglomerates are valued sufficiently, they selected the 45 largest listed banks (based on the balance sheet size, 2005) and the largest 45 insurers (based on gross written premiums, 2005). They determined the percentage of insurance activity (compared to the banking sector) based on the annual balance sheet data. After calculating all the data, the outcome of the first hypothesis, such as larger conglomerates, has more inefficient cross-subsidization opportunities and is therefore experiencing a larger reduction, is strongly confirmed for the EU mixed-money sample of sovereigns. The second hypothesis, as conglomerates become less opaque, is also confirmed by data, but to some extent less clear. The third hypothesis based on the risk shifting argument also has been confirmed. As risks decrease through diversification, value shifts from equity to debtholders, but an increase in risk positively affects the excess value.

Insurance companies and financial institutions have developed new products, as consumer needs and preferences change. In the article, "Does bancassurance add value for banks? - Evidence from mergers and acquisitions between European banks and insurance companies" , Zhian Chen and Jianzhong Tan , consider that is the first work that studies how risk affects acquisitions and mergers between insurance companies and banks.

Their empirical results shows that the risks according to purchasers remain constant, the growth of bancassurance mergers have an effect only on the systemic risk of the European banking system.

In the study "Bancassurance Impact on Bank Efficiency and Profitability: Banking Evidence in Taiwan," Jin-Lung Peng a, b, c, Vivian Jeng a, b, Jennifer L. Wang a, b, Chih Chen, consider that involvement in bancassurance activities, improved the efficiency and the

DOI: $10.2478 /$ picbe-2019-0016, pp. 171-181, ISSN 2558-9652| Proceedings of the $13^{\text {th }}$ International Conference on Business 
profitability of banks; the more involvement of banks in bancassurance activities is, the better performance is. In their research, concluded that the diversification strategy is very important, because as the income comes from different sources, the more banks are more sustainable. In his study, "Bancassurance Profitability for European Banks", Goran Bergendahl, presents a method of calculating profitability in the sale of insurance contracts. This research begin from the hypothesis that the development of bancassurance activity starts from three points. First of all, cross-selling activity in a bank branch will reduce costs. Second, selling insurance to the bank's clients will increase the chances of competition. In the end, it will be easier to sell insurance products attached to the bank's products, as a financial package. This study focused more on the costs and benefits of implementing bancassurance. Bergendahl concluded that those banks who have a larger customer base and a moderate number of branches, will be more profitable. It is important to provide lowcost and standardized products.

According of those studies and more, bancassurance activity brings important benefits to both the banking sector and insurance companies, increasing the efficiency of banking activity and profitability.

Factors that can positively or negatively impact bancassurance implementation can be internal or external. External factors include phenomena that cannot be influenced by the institution and internal factors that can be controlled. The external factors can be: the political, economic and financial climate, the legislation in the field, the international economic situation, the major force, etc. One of the most important factors influencing cooperation between insurers and banks is legislative regulation. There are no regulations in Romania that can hinder co-operation between banks and insurers.

Structural factors are: degree of bank / insurance integration; typology of products and their monitoring; the training and remuneration system of bankers; National regulations in the field - a decisive role in structuring the types of bancassurance partnerships; dominant position of the banking system compared to insurance companies.

Cultural Factors: the existence of a positive perception of banks ; low penetration rate of life insurance; substantial development potential; the relative absence of a credible alternative to the public pension.

Granting loans to individuals implies for the creditor bank to confront two major types of risk:

- the financial risk linked to the solvency and good faith of the applicant

- life risk linked to the possibility that a major event (death or permanent disability) may occur in the applicant's life to make it impossible to generate the income needed to repay the loan.

If in terms of financial risk banks have tools and policies of appreciation and monitoring that are verified by a long-term experience in terms of life risk, actuarial experience of insurers is clearly superior. This is why it is recommended that the credit applicant concludes a life insurance, given in favor of the creditor bank, which guarantees the repayment of the borrowed amounts even if it is unable to obtain the necessary incomes.

The risks associated to the banking or insurance institution, are almost the same, the financial institutions being exposed to the credit risk, market risk and operational risk.

DOI: 10.2478/picbe-2019-0016, pp. 171-181, ISSN 2558-9652| Proceedings of the $13^{\text {th }}$ International Conference on Business 
In Figure 2 , The relevance of risks for banks and insurance products, are presented differences between the products from different areas of activity (bank products, life insurance, non-life insurance) and the risks associated to the product.

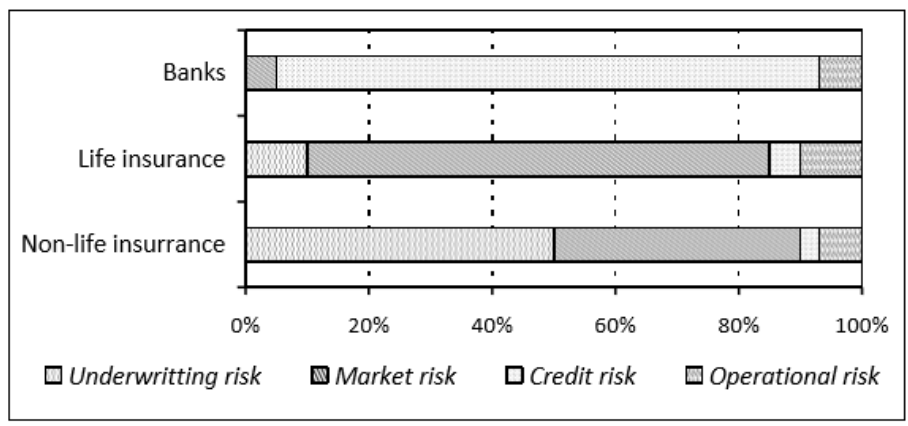

PICBE | 175

Figure 2. The relevance of risks for banks and insurance products

Source: Constantinescu, D- "The Influence of Bancassurance System on the Quality of the Insurance Services", 2012

In the banking sector the most relevant is credit risk, almost $90 \%$, in contrast to insurance sector where the credit risk does not exceed $10 \%$, but is exposed predominantely to market risk.

\section{Data and methodology}

In order to determine the bancassurance development, we used statistical quantitative models. In this analysis, we took into account the volume of credits granted, the volume of consumer loans, the volume of mortgages, Gross written premiums life insurance and Gross written premiums housing insurance.

The analisys was carried out on the basis of the Banking data, without taking into account other types of credits, apart from consumer credit and real estate credit.

The database was built using the data obtained from the publications and reports published on specialized websites of the National Bank of Romania and the Financial Supervisory Authority, the volumes of credits granted and gross written premiums, in the period 20132017.

Unfortunately, the lack of public information on bancassurance activity in the Romanian banking system leads to a limitation of the thorough studies on the impact of the bancassurance system on efficiency and profitability on the banking system, as well as the lack of public reports on the evolution of loans granted and gross written premiums, has limited the analysis for the last 5 years.

Table 1. Evolution of volume of credits and GWP during 2013-2017

\begin{tabular}{|l|l|l|l|l|l|}
\hline \multicolumn{7}{|c|}{ Table 1. Evolution of volume of credits and GWP during 2013-2017 } & [bn RON] \\
\hline Volume of credits granted & $\mathbf{2 0 1 3}$ & $\mathbf{2 0 1 4}$ & $\mathbf{2 0 1 5}$ & $\mathbf{2 0 1 6}$ & $\mathbf{2 0 1 7}$ \\
\hline Volume of customer loans & 220095.15 & 213302.81 & 220075.96 & 222947.62 & 235031.50 \\
\hline Volume of mortgages & 53607.63 & 54421.64 & 53003.96 & 52288.63 & 53888.09 \\
\hline $\begin{array}{l}\text { Gross written premiums life } \\
\text { insurance }\end{array}$ & 40954.02 & 44702.47 & 52092.74 & 58592.97 & 66275.83 \\
\hline $\begin{array}{l}\text { Gross written premiums } \\
\text { housing insurance }\end{array}$ & 1493.75 & 1374.92 & 1577.50 & 1669.84 & 2026.67 \\
\hline
\end{tabular}

Source: author's based on data from BNR and ASF

DOI: $10.2478 /$ picbe-2019-0016, pp. 171-181, ISSN 2558-9652| Proceedings of the $13^{\text {th }}$ International Conference on Business Excellence 2019 


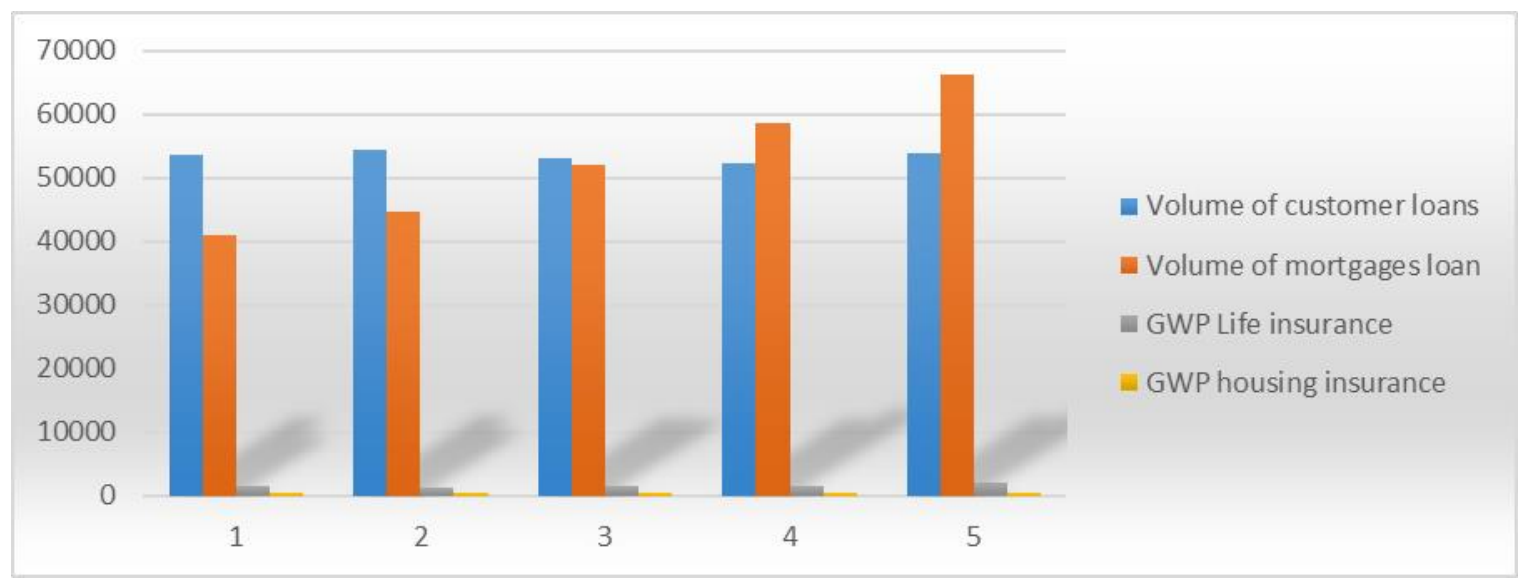

PICBE $\mid 176$

Chart 2. Evolution of volume of credits and GWP during 2013-2017

Stages of calculation

Source: author's based on data from BNR and ASF

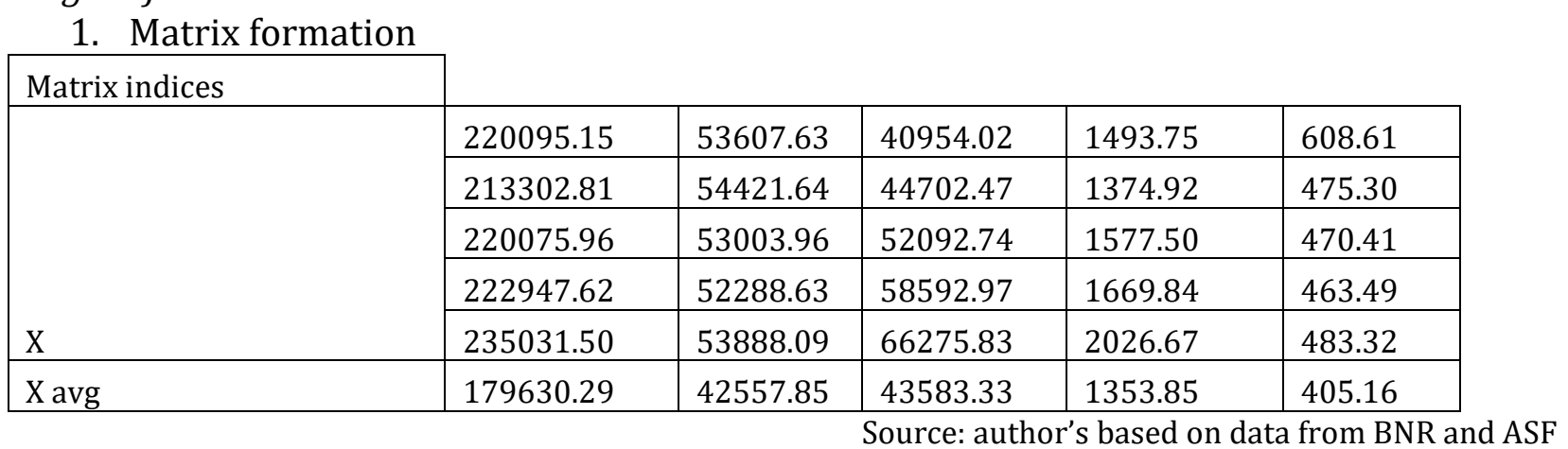

2. Standardization

Values expressed in different units of measurement can not be compared directly requiring a transformation of the original data by standardization. Standardization is done by extracting the average value of the variable from each original value and dividing the difference by the standard deviation. Standardization can have a decisive influence on the structure of the variant-covariance matrix and consequently on the results of the factorial analysis if the variables' amplitudes of the variables differ significantly and the distributions are strongly asymmetric.The effect of standardization is to extend both variables on the same value range.

3. Calculating indices

$\mathrm{Z}=\mathrm{X}_{\mathrm{i}} / \mathrm{X}_{\text {avg }}$, where

$\mathrm{Z}$ - standard index; $\mathrm{Xi}$ - value of X-index in i-period, Xavg. - average value.

After the calculating the indices, the matrix will have the following values:

Standard Indices Matrix

\begin{tabular}{|l|l|l|l|l|l|}
\hline \multirow{5}{*}{$\mathrm{Z}$} & 1.23 & 1.26 & 0.94 & 1.10 & 1.50 \\
\cline { 2 - 7 } & 1.19 & 1.28 & 1.03 & 1.02 & 1.17 \\
\cline { 2 - 7 } & 1.23 & 1.25 & 1.20 & 1.17 & 1.16 \\
\cline { 2 - 7 } & 1.24 & 1.23 & 1.34 & 1.23 & 1.14 \\
\cline { 2 - 6 } & 1.31 & 1.27 & 1.52 & 1.50 & 1.19 \\
\hline
\end{tabular}


The following factors have positive effects on the cooperation of banks and insurance companies: the volume of customer credits, the volume of mortgage loans, credit insurance, asset insurance and life insurance.

Increasing the mentioned factors means improving the activity of banks and insurance companies, increasing profits and increasing the customer base.

4. Calculation of vectors

$\mathrm{P}_{\mathrm{o}}$

The next step in calculating the optimal capital structure index is detecting the space between the separate observations (periods) and the standard vector. The space between the separate comments point and point $\mathrm{P} 0$ is calculated according to the following formula:

Zij- standard value of $\mathrm{i}$

$$
\text { Cio }=\sqrt{\sum(Z i j-Z o j) 2} \text { where }
$$

Zoj-standard value of $\mathrm{j}$

$\mathrm{C}_{\mathrm{i} 1}=0.7573$

$\mathrm{C}_{\mathrm{i} 2}=0.77058$

$\mathrm{C}_{\mathrm{i} 3}=0.5765$

$\mathrm{C}_{\mathrm{i} 4}=0.49223$

$\mathrm{C}_{\mathrm{i} 5}=0.31016$

5. Calculate the mean of the observations according to the formula:

$$
\text { Co }=\frac{1}{\mathrm{~m}} \sum \text { Cio }
$$

$\mathrm{C}_{0}=0.58$

I will also calculate the mean deviation (S0), the maximum deviation of the model $\left(\mathrm{C}_{0}\right)$ and the dynamic dynamics index of the growth level (di) according to the formulas:

$$
S o=\sqrt{\frac{1}{\mathrm{~m}} \sum(\mathrm{Cio}-\mathrm{Co}) 2}
$$

$\mathrm{S}_{0}=0.17$

$\mathrm{C}_{0}=\mathrm{C}_{0}+2 \mathrm{~S}_{0}$

$\mathrm{D}_{\mathrm{i}}=\mathrm{C}_{\mathrm{io}} / \mathrm{C}_{\mathrm{o}}$

$\mathrm{C} 0=\mathrm{C} 0^{-}+2 \mathrm{~S}_{0}=0.92$

$\mathrm{di}=\mathrm{Cio} / \mathrm{Co}$

$\mathrm{d}_{2013}=0.81$

$\mathrm{d}_{2014}=0.83$

$\mathrm{d}_{2015}=0.61$

$\mathrm{d}_{2016}=0.53$

$\mathrm{d} 2017=0.33$

The taxonomic coefficient is calculated by the formula:

$\mathrm{K}_{\mathrm{i}}=1-\mathrm{d}_{\mathrm{i}}$

As a measure of the similarity between two objects, the coefficient of the taxonomic distance originates in the geometric model of the Euclidean distance between two points $\mathrm{A}$

DOI: 10.2478/picbe-2019-0016, pp. 171-181, ISSN 2558-9652| Proceedings of the $13^{\text {th }}$ International Conference on Business

Excellence 2019 
and $\mathrm{B}$ in an $\mathrm{n}$-dimensional space. Increasing the number of features used reduces the possibility of interpreting the value of the taxometric distance compared to other correlation coefficients due to the diversity of the measurement units and the selection amplitudes. The elimination of these inconveniences is accomplished by standardizing the values of the measured characteristics, normalizing them on the interval $[1,0]$ and defining the coefficient of the taxonomic distance:

PICBE | 178

$\mathrm{K}_{2013}=0.19$

$\mathrm{K}_{2014}=0.17$

$\mathrm{K}_{2015}=0.39$

$\mathrm{K}_{2016}=0.47$

$\mathrm{K}_{2017}=0.67$

Under these conditions, the extreme values of the distance coefficient are: zero when the two samples are identical, thus the similarity is maximum and one when the two samples A and $\mathrm{B}$ are totally different.

6. Calculating the regression equation

The regression equation will take the form:

$\mathrm{y}$ - dependent variable (bancassurance)

$$
y=\beta_{0}+\beta_{1} x \text {, where }
$$

$\mathrm{x}$ - independent variable (volume of credits)

$\beta_{0}, \beta_{1}$ - parameters

$\beta_{0}$ represents the intersection of the equation line with the vertical axis, this value being obtained for $x=0$. From the point of view of the study, there is no insurance sold in the bank. The value of $\beta_{0}$ therefore means that this is the level of "autonomous" sales from customers who purchase insurance within the bank.

$\beta 1$ is the slope, or the inclination of the straight line. For a linear function this slope is the same everywhere and has the following meaning: if the value of $x$ increases with a unit, then the value of $y$ changes in the sense of increasing or decreasing with $\beta 1$ units, depending on the (positive or negative) sign of $\beta_{1}$.

The method used to estimate regression equation parameters is known as the Smallest Square Method and involves determining $\beta_{0}, \beta_{1}$ so as to minimize the expression:

$$
S P E=\sum_{i=1}^{5}\left(y_{i}-\hat{y}\right)^{2}
$$

$\beta_{0}, \beta_{1}$ will be calculated as follows:

$$
\begin{gathered}
\beta_{1} \wedge=\frac{\sum\left(x_{i}-\bar{x}\right)\left(y_{i}-\bar{y}\right)}{\Sigma\left(x_{i}-\bar{x}\right)^{2}} \quad \text { or } \beta_{1} \wedge=\frac{\sum \mathrm{x}_{\mathrm{i}} \mathrm{y}_{\mathrm{i}}-\frac{1}{\mathrm{n}} \sum \mathrm{x}_{\mathrm{i}} \cdot \Sigma \mathrm{y}_{\mathrm{i}}}{\sum x_{i}^{2}-\frac{1}{n}\left(\sum x_{i}\right)^{2}} \\
\beta_{0} \wedge=\bar{y}-\beta_{1} \wedge \bar{x}
\end{gathered}
$$

$\sum \mathrm{x}_{\mathrm{i}}=1.89$

$\sum y_{i}=6.20$

$\mathrm{x}^{-}=0.378$

$\mathrm{y}^{-}=1.24$

$\sum \mathrm{Xi}^{2}=0.8869$

DOI: $10.2478 /$ picbe-2019-0016, pp. 171-181, ISSN 2558-9652| Proceedings of the $13^{\text {th }}$ International Conference on Business 
$\sum \mathrm{x}_{\mathrm{i}} \mathrm{y}_{\mathrm{i}}=2.3762$

$\beta_{1}=0.1878$

$\beta_{0}=1.169$

$\mathrm{y}=1.169+0.1878 \mathrm{x}$

The slope of the estimated equation of regression is 0.1878 and takes a positive value, which means that if the volume of credits granted is higher, also the insurance sales within the bank will be higher.

7. Calculation of the determination coefficient

Given that the idea of estimation entails suspicions about the accuracy of the result and implicitly suggests potential errors from the difference between estimated values and actual values. When the theory provides us with two or more estimation methods, it is conceived that differences can occur not only between estimated and observed values but also between estimates obtained by different methods.

$$
\mathrm{SPT}=\sum_{i=1}^{n}\left(y_{i}-\bar{y}\right)^{2}
$$

The expression is the sum of the squares of the deviations of the sample data compared to the average selection value. The differences that occur between the two estimation variants, the one in which the estimated regression equation was used and the one in which we used the calculated sample based on the sample data.

$$
\mathrm{SPR}=\sum_{\mathrm{i}=1}^{\mathrm{n}}(\hat{\mathrm{y}}-\bar{y})^{2}
$$

The determination coefficient is the magnitude reflecting the extent to which the estimated regression equation can be used in the forecasts. Write down with $\mathrm{r}^{2}$ and calculate by the formula:

$$
\mathrm{r}^{2}=\frac{S P R}{S P T}, \mathrm{r}^{2} \in[0,1]
$$

The determination coefficient expresses the percentage of SPT that can be explained by the use of the estimated regression equation. It can also be used as a measure of the degree of approach of the regression line by the points of the scatter diagram, in the sense that a high value of $r^{2}$ tells us that the approximation is very good. Last but not least, $\mathrm{r}^{2}$ expresses a measure of the intensity of the regression relationship: more precisely, $r^{2}$ is greater the relationship is stronger, whereas a small value of $\mathrm{r}^{2}$ shows a weak relationship.

\begin{tabular}{|l|l|l|l|}
\hline \multicolumn{1}{|c|}{$\mathbf{y i}_{\mathbf{i}}$} & $\bar{y}$ & \multicolumn{1}{c|}{$\mathbf{y i}_{\mathbf{i}}-\bar{y}$} & \multicolumn{1}{|c|}{$\left(\mathbf{y i}_{\mathbf{i}}-\bar{y}\right)^{2}$} \\
\hline 1.23 & 1.24 & -0.01 & 0.0001 \\
\hline 1.19 & 1.24 & -0.05 & 0.0025 \\
\hline 1.23 & 1.24 & -0.01 & 0.0001 \\
\hline 1.24 & 1.24 & 0.00 & 0 \\
\hline 1.31 & 1.24 & 0.07 & 0.0049 \\
\hline SPT & \multicolumn{2}{|l}{} & 0.0076 \\
\hline
\end{tabular}

\begin{tabular}{|r|r|c|c|}
\hline$\hat{y}$ & $\bar{y}$ & $\hat{y}-\bar{y}$ & $(\hat{y}-\bar{y})^{2}$ \\
\hline 1.204682 & 1.24 & -0.03532 & 0.001247361 \\
\hline 1.200926 & 1.24 & -0.03907 & 0.001526777 \\
\hline 1.242242 & 1.24 & 0.002242 & $5.02656 \mathrm{E}-06$ \\
\hline 1.257266 & 1.24 & 0.017266 & 0.000298115 \\
\hline
\end{tabular}

DOI: 10.2478/picbe-2019-0016, pp. 171-181, ISSN 2558-9652| Proceedings of the $13^{\text {th }}$ International Conference on Business Excellence 2019 


\begin{tabular}{|l|l|l|l|}
1.294826 & 1.24 & 0.054826 & 0.00300589 \\
\hline SPR & 0.00608317 \\
\hline
\end{tabular}

$\mathrm{r}^{2}=\mathrm{SPR} / \mathrm{SPT}=0.0060 / 0.0076=0.800417131$

In percentage terms we obtain $\mathrm{r}^{2}=80.04 \%$, so the relationship between bancassurance and the volume of credits granted is quite intense. In other words, the percentage of $80.04 \%$ shows the extent to which the variation in loans granted is explained by the variance of the insurance sold within the bank.

Also, according to the calculation, I obtain for The Pearson Coefficient, $r=0.90041$, which demonstrates also a strenght relation between the variables.

\section{Conclusion}

The implementation of Bancassurance within banks as a distribution channel, has many advantages, especially for banks, because beside the commissions obtained from selling the insurance products, the main advantage is the possibility of immediate recovery of the credit balance, in case of the death or invalidity of debtor. Even according to Insurance Distribution Directive is forbidden for distributors to present the products as a set loan with insurance), is very important to convince the client that closing the life insurance when they contracting a loan is the most safely method for reimbursement the loan, in case of producing an event.

According to the calculations, the $80.04 \%$ indicates that the variance of the insurance sold through the bank distribution channel is explained by the variance of the credits granted.

The implementation of Bancassurance activity in the banking system leads to improvement of efficiency and increasing the profitability of bank sector, ensure the satisfaction and cover the financial needs of customers in the same financial institution.

\section{References}

Basel Committee on Banking Supervision (2010) - Basel III: A global regulatory framework for more resilient banks and banking systems. Retrieved from https://www.bis.org/ $\mathrm{publ} / \mathrm{bcbs189.pdf}$, accesed on 03.01.2019

Bergendahl,G.. (1995). The Profitability of Bancassurance for European banks. International Journal of Bank Marketing, Vol. 13, No. 1, pp. 17-29.

Cetina, I., Odobescu, E. (2007). Banking Marketing Strategies. Bucharest: Editura Economica, pp 201-203.

Chen,Z, Tan,Z. (2011) . Does bancassurance add value for banks? -Evidence from mergers and acquisitions between European banks and insurance companies, School of Banking \&Finance, The University of New South Wales, NSW 2052, Sydney, Australia, Research in International Business and Finance 25, pp. 104-112.

Chiang Ku Fan1, Yu Hsuang Lee (2010). Key Factors Influencing Bancassurance Success Mainland China Evidence, China, Journal Service Science \& Management,3, 520-528, 2010

Clipici, E.,Bolovan,C.(2012). Bancassurance - main insurance distribution and sale channel in Europe. Scientific Bulletin - Economic Sciences, University of Pitesti, vol. 11(Special).

DOI: 10.2478/picbe-2019-0016, pp. 171-181, ISSN 2558-9652| Proceedings of the $13^{\text {th }}$ International Conference on Business Excellence 2019 
Constantinescu, D.(2012) . The Influence of Bancassurance System on the Quality of the Insurance Services, Ecological University of Bucharest, Romania, International Journal of Academic Research in Business and Social Sciences, Vol. 2, No. 10 ISSN: 2222-6990

Druica, E. N. (2011). Econometry Course. Retrieved from http://old.unibuc.ro/prof/druica_e_n/docs/res/ 2011apr Econometrie_-_suport_ PICBE|181 de_curs .pdf.

European Commission, 2002, Directive 2002/87/CE of Europeam Parliament and of the Council of 16 december 2002 on the supplementary supervision of credit institutions, insurance undertakings and investment firms in a financial conglomerate and modification of Directives 73/239/CEE, 79/267/CEE, 92/49/CEE, 92/96/CEE, 93/6/CEE and 93/22/CEE of Council and Directives 98/78/CE and 2000/12/CE of European Parliament and Council. Retrieved on https://eur-lex.europa.eu/legal-content/RO/ALL/?uri=CELEX\%3A32002L00 87 ;

European Commission, 2014, Directive 2014/65/UE of European Parliament and of the Council of 15 May 2014 , according on financial instruments market and modification of Directive 2002/92/CE and of Directive 2011/61/UE (reformation) (pp 128-129). Retrieved on https://asfromania.ro/files/capital/mifidmifir/DIRECTIVA\%2065.2014.pdf;

Financial Supervisory Authority.(2013-2017). Insurance bulletins. Retrieved from: https://asfromania.ro/ publicatii/ buletine-informative/buletine-asigurari.

Gonulal, S.,Goulder, N., Lester ,R. (2012) . Bancassurance-A Valuable Tool for Developing Insurance in Emerging Markets .The World Bank Financial and Private Sector Development, Non-Bank Financial Institutions. Retrieved from: http://documents.worldbank.org/curateden/725931468056443105/pdf/wps6196. pdf

Hota,S. (2016). Bancassurance: Convergence of Banking and Insurance - A Saga - SAI International College of Commerce, Bhubaneswar.

Insurance Europe (2016). European Insurance in Figures. Retrieved from https://www.insuranceeurope.eu/sites/default/files/attachments/WEB_European \%20Insurance\%20in\%20Figures\%20-\%202016\%20data.pdf .

Lelyveld, I.,Knot,K. (2008). Does conglomerates destroy value or not? Evidence for the EU, De Nederlandsche Bank Eurosystem.

National Bank of Romania (2013-2017). Publications. Retrieved from http://www.bnro.ro/Publicatii-4.aspx .

Rusul,L.V(2017). Candidate of Economic Sciences- Bancassurance under financial globalization in Ukraine, Scientific bulletin of Polissia № 2 (10), P. 2.

Schmid, M.M. , Walter, I (2009). Do financial conglomerates create or destroy economic value Journal Financial Intermed. 18 (2), pp193-216.

Scradeanu, D.(2013). Quantitative statistical models. Retrieved from: http://old.unibuc.ro/prof/scradeanu_d/docs/2013/noi/08_21_27_123_Modele_CAN TITATIVE_STATISTICE_DSCRD.pdf 